\title{
PERANCANGAN SISTEM APLIKASI PERMOHONAN CUTI KARYAWAN PT BAREKSA PORTAL INVESTASI
}

\author{
Selviana Sofyan ${ }^{1}$, Dian Hermanto ${ }^{2}$, Muslihatul Hidayah ${ }^{3}$ \\ Program Studi Teknik Informatika, Fakultas Teknik dan Ilmu Komputer, \\ Universitas Indraprasta PGRI \\ Jalan Raya Tengah No 80, Kelurahan Gedong, Pasar Rebo, Jakarta Timur \\ Selviana22sofyan98@gmail.com¹, dianh.lectures@gmail.com², muslihatulhidayah@gmail.com³
}

\begin{abstract}
Abstrak
Tujuan penelitian ini adalah untuk menganalisa sistem pengolahan permohonan cuti karyawan serta laporan yang ada di PT Bareksa Portal Investasi saat ini belum terkomputerisasi. Penelitian ini juga bermaksud untuk membuat dan membantu dalam proses penyelesaian masalah tersebut, sehingga karyawan dapat dengan mudah mengetahui sisa cuti yang ia miliki dan memudahkan kepala divisi dalam melakukan proses persetujuan cuti. Metode penelitian yang digunakan untuk perancangan sistem aplikasi permohonan cuti karyawan adalah grounded research dengan pendekatan kualitatif dan teknik pengumpulan data dengan studi lapangan dengan pengamatan langsung (observasi) dan wawancara. Selain itu juga, peneliti melakukan pengumpulan data dengan studi kepustakaan berdasarkan referensi dan berbagai media yang memuat informasi yang diperlukan untuk menganalisa kebutuhan, perancangan, pengujian dan pemilihan sistem. Sistem ini dibuat menggunakan bahasa pemrograman java dan bantuan database MYSQL. Hasil penelitian ini adalah Sistem informasi PT Bareksa Portal Investasi telah terkomputerisasi dengan sistem aplikasi berbasis java, karyawan lebih mudah mengetahui sisa cuti yang ia miliki, waktu persetujuan yang diberikan kepala divisi menjadi lebih cepat.
\end{abstract}

Kata Kunci: sistem, aplikasi, permohonan cuti karyawan

\begin{abstract}
The purpose of this study is to analyze the processing system of employee leave applications as well as reports in PT Bareksa Investment Portal currently not computerized. The research also intends to create and assist in the process of resolving the problem, so that employees can easily find out the rest of the leave he has and make it easier for the division head to carry out the leave approval process. The research method used for the design of the employee leave application application system is grounded research with qualitative approach and data collection techniques with field studies with direct observation (observation) and interviews. In addition, researchers collect data with literature studies based on references and various media that contain information needed to analyze the needs, design, testing and selection of systems. The system is created using the java programming language and mySQL database assistance. The result of this research is that the information system of PT Bareksa Investment Portal has been computerized with a java-based application system, employees are easier to find out the rest of the leave he has, the approval time given by the division head becomes faster.
\end{abstract}

Keyword: systems, applications, requests for employee leave

\section{PENDAHULUAN}

Seiring dengan perkembangan teknologi yang begitu pesat, sistem informasi yang berbasis java dimanfaatkan sebagai sarana peningkatan informasi. Pemanfaatan tersebut akan mempermudah suatu pekerjaan seperti halnya pengolahan data lebih cepat, keputusan yang akan diambil lebih tepat, menghemat waktu dan biaya. Sebagian besar dari sistem pelayanan PT Bareksa Portal Investasi kepada nasabah bersifat secara online dan terkomputerisasi. Sayangnya, sistem terkomputerisasi masih belum diterapkan untuk karyawan, salah satunya adalah ketika ingin mengajukan permohonan cuti. Oleh karena itu, untuk memberikan kemudahan para karyawan melakukan permohonan cuti kita perlu membuat suatu program yang mampu menunjang dalam kegiatan operasionalnya. Sistem informasi permohonan cuti dapat memberikan kemudahan para karyawan dalam mengajukan permohonan cuti serta mendapatkan informasi yang berhubungan dengan cuti secara lengkap dan terperinci. Begitupun bagian kepegawaian, diharapkan sistem Aplikasi Permohonan Cuti yang terkomputerisasi ini efektif mengganti sistem yang masih bersifat manual. Kedepannya para karyawan tidak harus mengisi form 
cuti secara manual tetapi cukup mengisi form cuti yang terkomputerisasi dan dapat mengetahui sisa cuti yang ia miliki sehingga pemrosesan cuti lebih mudah dan cepat. Sistem adalah suatu jaringan kerja dari prosedur-prosedur yang berhubungan, terkumpul bersama-sama untuk melakukan suatu kegiatan atau tujuan tertentu (Yakub, 2012). Sistem adalah himpunan dari bagian-bagian yang saling berhubungan yang secara bersamaan mencapai tujuan-tujuan yang sama (Hutahaean, 2015). Aplikasi adalah perangkat lunak (software) yang digunakan untuk tujuan tertentu, seperti mengolah dokumen, mengatur windows 7, permainan(game), dan sebagainya (Hakim, 2010).

\section{PENELITIAN RELEVAN}

Beberapa penelitian yang relevan dengan penelitian ini adalah :

Penelitian oleh (Haryani, 2017) dengan judul "Sistem Informasi Pengambilan Cuti Pegawai Berbasis Desktop Pada PT Bs Logistics Batam". Hasil penelitian menunjukkan bahwa dengan adanya sistem informasi ini, dapat mempermudah pembuatan laporan cuti pegawai serta mempermudah bagian HR dan keuangan dalam memberikan laporan ke pimpinan. Penelitian oleh (Basuki, 2011) dengan judul "Perancangan Aplikasi Sistem Informasi Cuti Karyawan Berbasis Web Pada Pt Integrasi Tri Tama Cendekia". Hasil penelitian menunjukkan bahwa Dengan adanya aplikasi cuti online, karyawan diharapkan dapat menerima informasi yang lebih tentang kepegawaian khususnya permasalahan cuti. Sistem cuti online yang dibuat dapat mempermudah proses pengajuan dan persetujuan Cuti. Dengan sistem cuti online, proses pengajuan usulan cuti bisa dilakukan tanpa harus bertatap muka secara langsung.

\section{METODE PENELITIAN}

Metode penelitian yang digunakan adalah metode grounded research, yaitu suatu metode penelitian berdasarkan fakta dan menggunakan analisis perbandingan dengan tujuan mengadakan generalisasi empiris, menetapkan konsep, membuktikan teori, mengembangkan teori, pengumpulan dan analisis data dalam waktu yang bersamaan (Nazir, 2011). Untuk mendapatkan data dan informasi guna mendukung penyempurnaan hasil dari penelitian ini, maka peneliti melakukan metode pengumpulan yang di antara lain :

1. Metode Interview (Wawancara) Teknik wawancara yang digunakan dalam penelitian ini adalah menggunakan teknik wawancara yang terstruktur. Proses wawancara dilakukan secara terencana untuk mendapatkan informasi dari narasumber

2. Metode Observasi (Pengamatan Langsung) Observasi adalah bagian dalam pengumpulan data Observasi berarti mengumpulkan data langsung dari lapangan (Semiawan, 2010).

3. Metode Studi Kepustakaan (Literature) Studi Kepustakaan adalah segala usaha yang dilakukan oleh peneliti (Hermawan, 2019).

\section{HASIL DAN PEMBAHASAN}

Data Flow Diagram atau Diagram Alir Data adalah refresentasi grafik yang menggambarkan aliran informasi dan transformasi informasi yang diaplikasikan sebagai data yang mengatur dari masukan (input) dan keluaran (output) (Sukamto \& Shalahuddin, 2015). Berikut ini merupakan gambaran tentang sistem yang diusulkan pada Sistem aplikasi permohonan cuti PT Bareksa Portal Investasi secara keseluruhan dalam bentuk diagram konteks : 


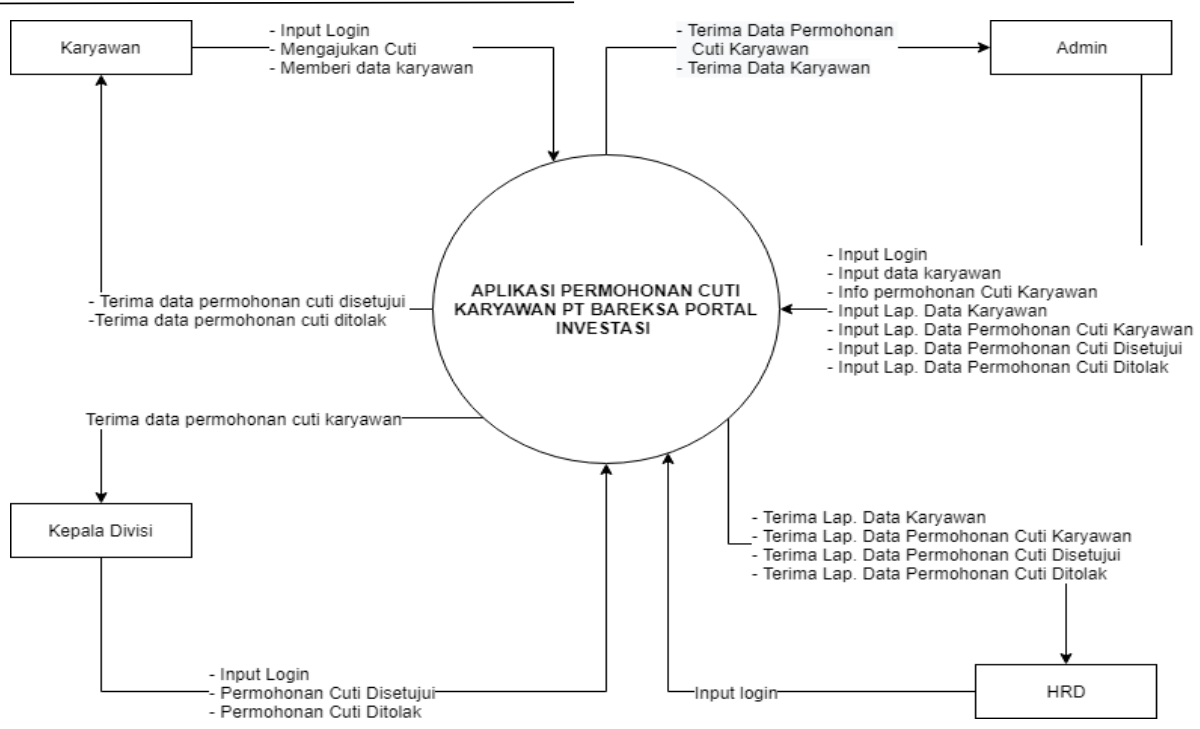

Gambar 1. Data Flow Diagram

Pada Diagram Konteks yang diusulkan, terdapat gambaran keseluruhan proses yang dapat dilihat dari mulai karyawan mengajukan cuti sampai HRD mendapatkan laporan-laporan data permohonan cuti.

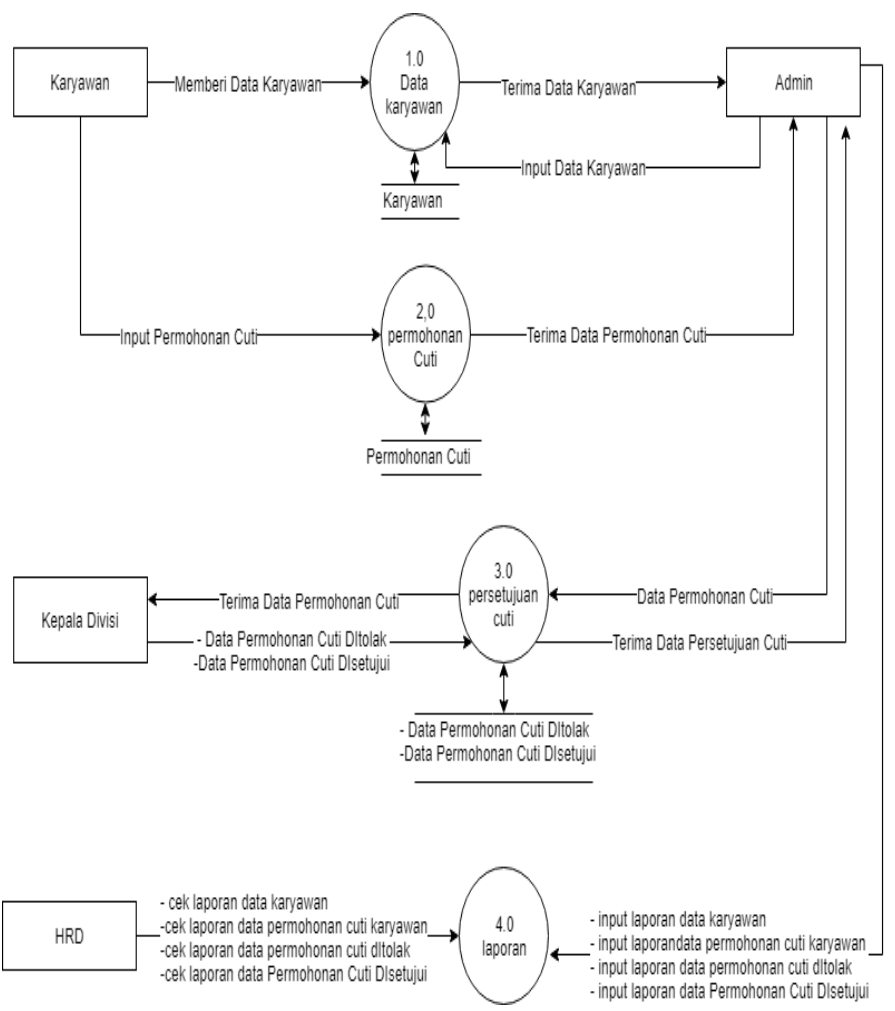

Gambar 2. Data Flow Diagram Level Nol

Pada diagram level nol terlihat lebih rinci dari gambar diagram konteks. Diagram nol terdapat empat proses yang semua masing-masing proses mempunyai alur tersendiri dan proses terlihat lebih terarah pada diagram level nol yang diusulkan.

Entity Relationship Diagram (ERD) adalah suatu permodelan berbasis pada persepsi dunia maya yang mana terdiri dari kumpulan objek dasar yang disebut dengan entitas dan hubungan diantara objek- 
objek tersebut dengan menggunakan perangkat konseptual dalam bentuk (Lubis, 2016). Berikut ini merupakan gambaran tentang sistem yang diusulkan pada Sistem Aplikasi Permohonan Cuti PT Bareksa Portal Investasi secara keseluruhan dalam bentuk entity relationship diagram :

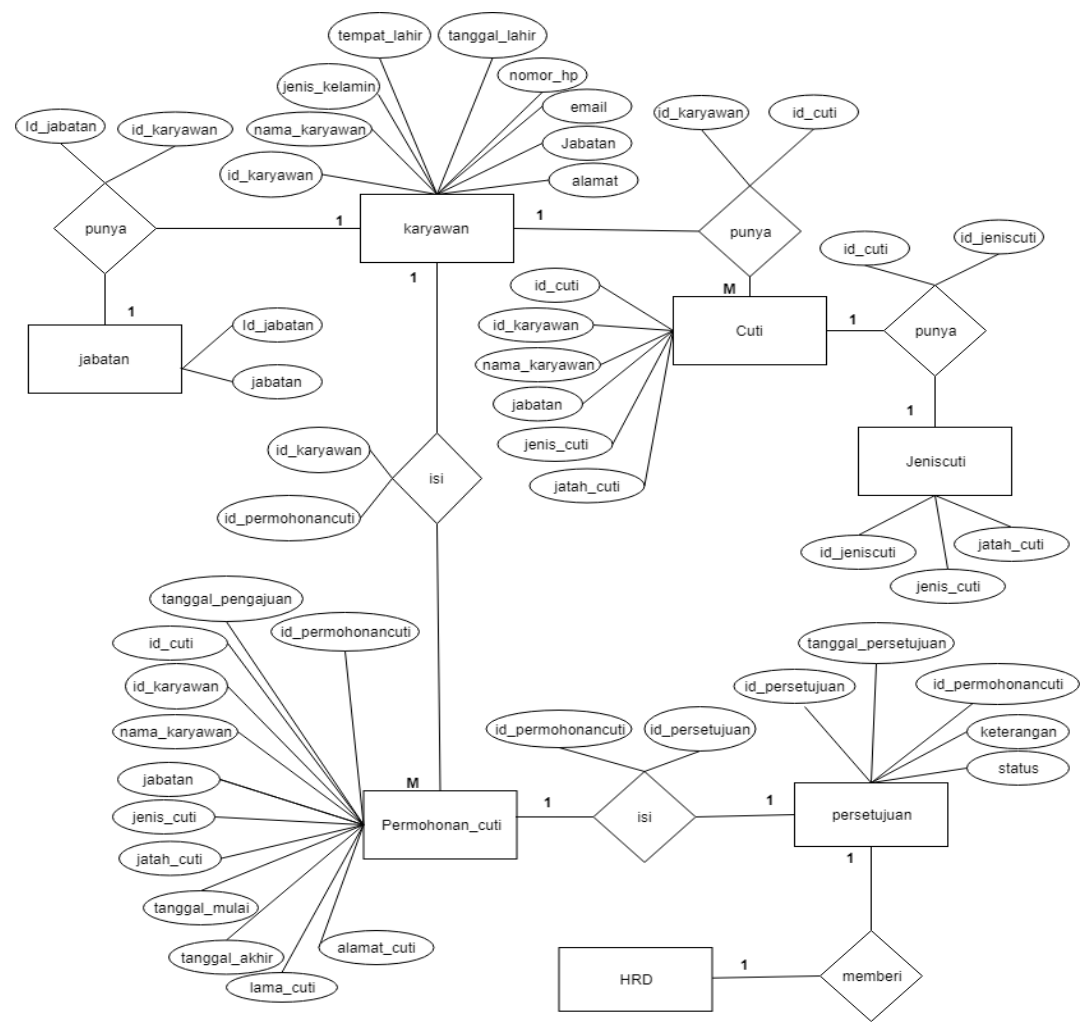

Gambar 3. Entity Relation Ship

Pada entity relationship diagram menjelaskan bahwa karyawan melakukan permohonan cuti setelah itu data permohonan cuti tersebut akan diberi persetujuan oleh HRD.

\section{Tampilan Layar, Tampilan Format Masukan Dan Tampilan Keluaran.}

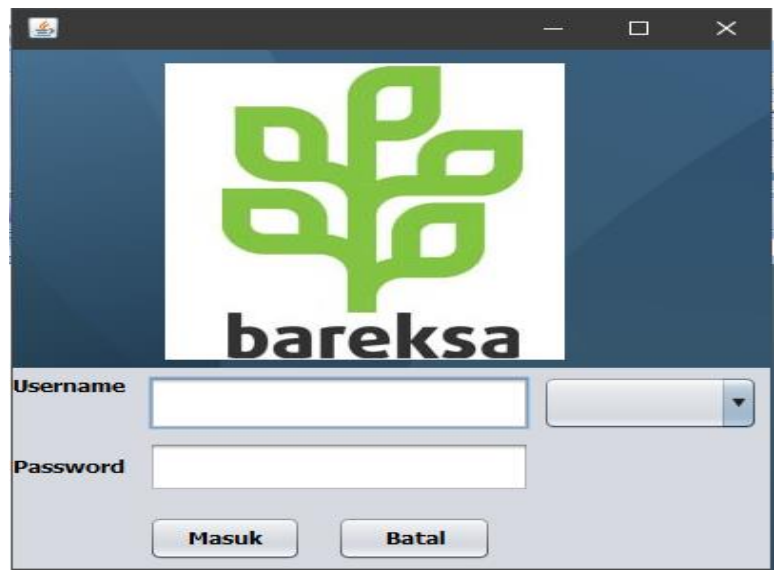

Gambar 4. Tampilan login

Pada tampilan menu login, setiap pengguna akan diarahkan untuk mengisi username dan password sesuai akses yang sudah ditentukan. 


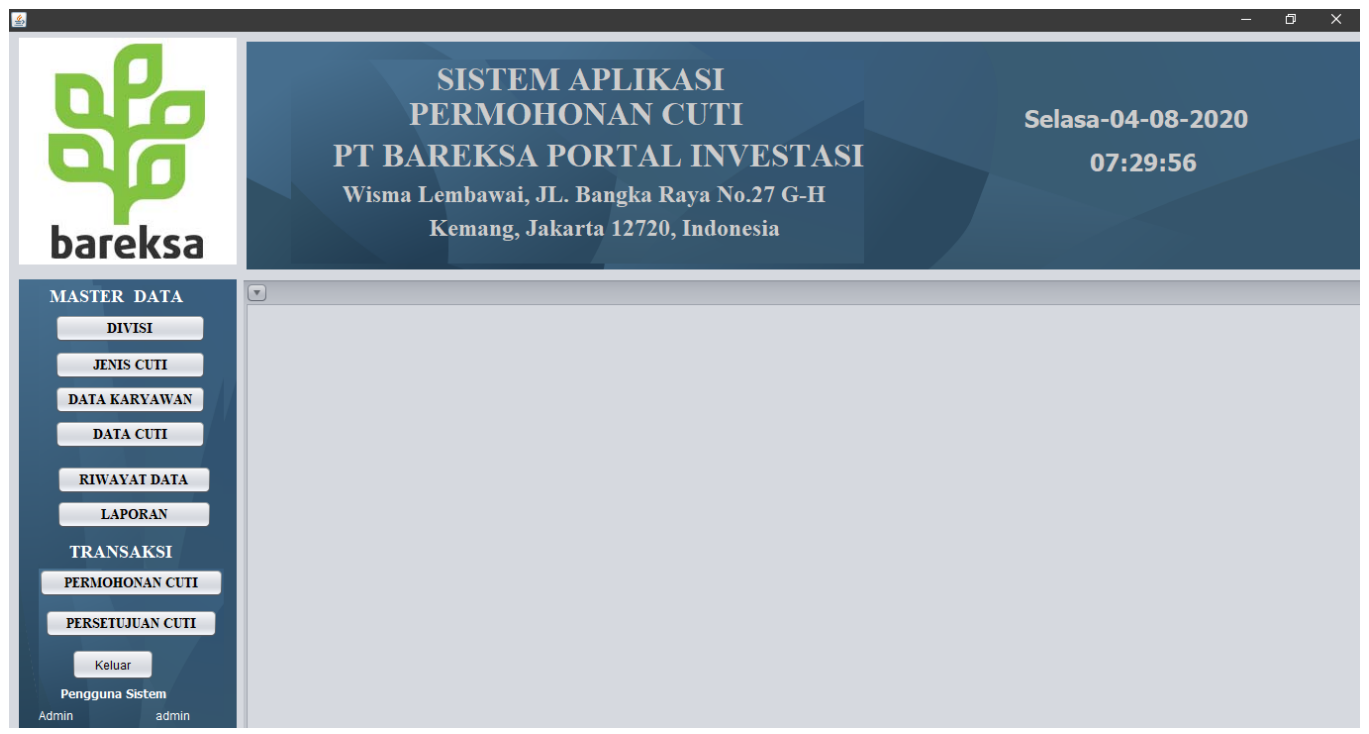

Gambar 5. Menu Utama

Pada tampilan menu utama terdapat banyak tombol yang hanya boleh diakses sesuai dengan user acces masing - masing dan juga terdapat tombol data data master dan transaksi.

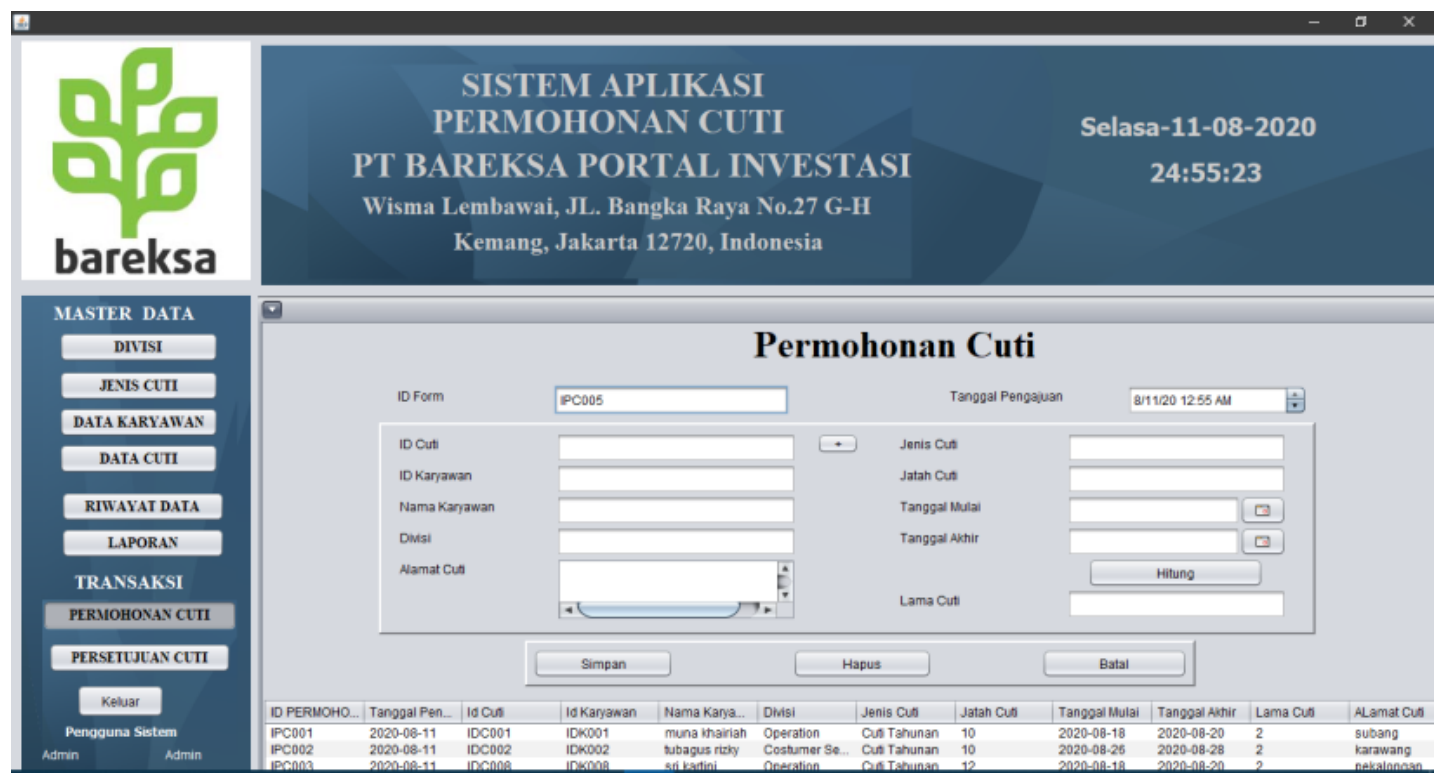

Gambar 6. Proses Form Permohonan Cuti

Jika kita klick tombol permohonan cuti maka akan tampil seperti gambar diatas. Ini adalah form menu permohonan cuti, yang mana bisa diakses oleh user tertentu. Didalamnya terdapat banyak tombol, seperti tombol Simpan, Batal, Ubah, dan Hapus serta ada ada juga tabel yang berisikan data permohonan cuti, Menu ini digunakan jika ingin menambah, mengubah dan menghapus permohonan cuti. Serta ada juga tombol cari yang berfungsi untuk mencari data permohonan cuti yang kita inginkan. 


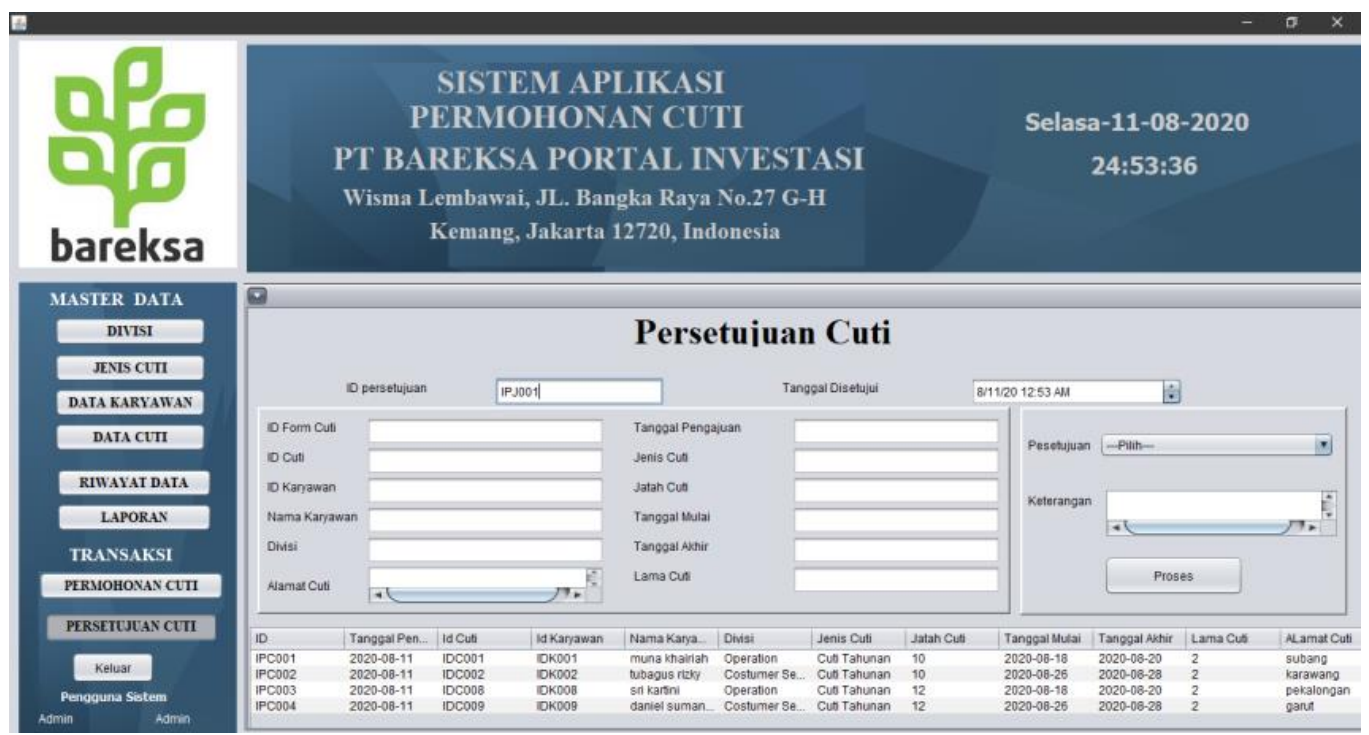

Gambar 7. Proses Form Persetujuan Cuti

Form ini digunakan untuk memberi persetujuan cuti yang telah diajukan pada from permohonan cuti. Jika kita klick tombol persetujuan cuti maka akan tampil seperti gambar diatas. Ini adalah form menu permohonan cuti, yang mana bisa diakses oleh user tertentu. Didalamnya terdapat tombol proses pada menu ini, menu ini berfungsi untuk memberikan persetujuan terhadap karyawan yang telah mengajukan permohonan cuti.

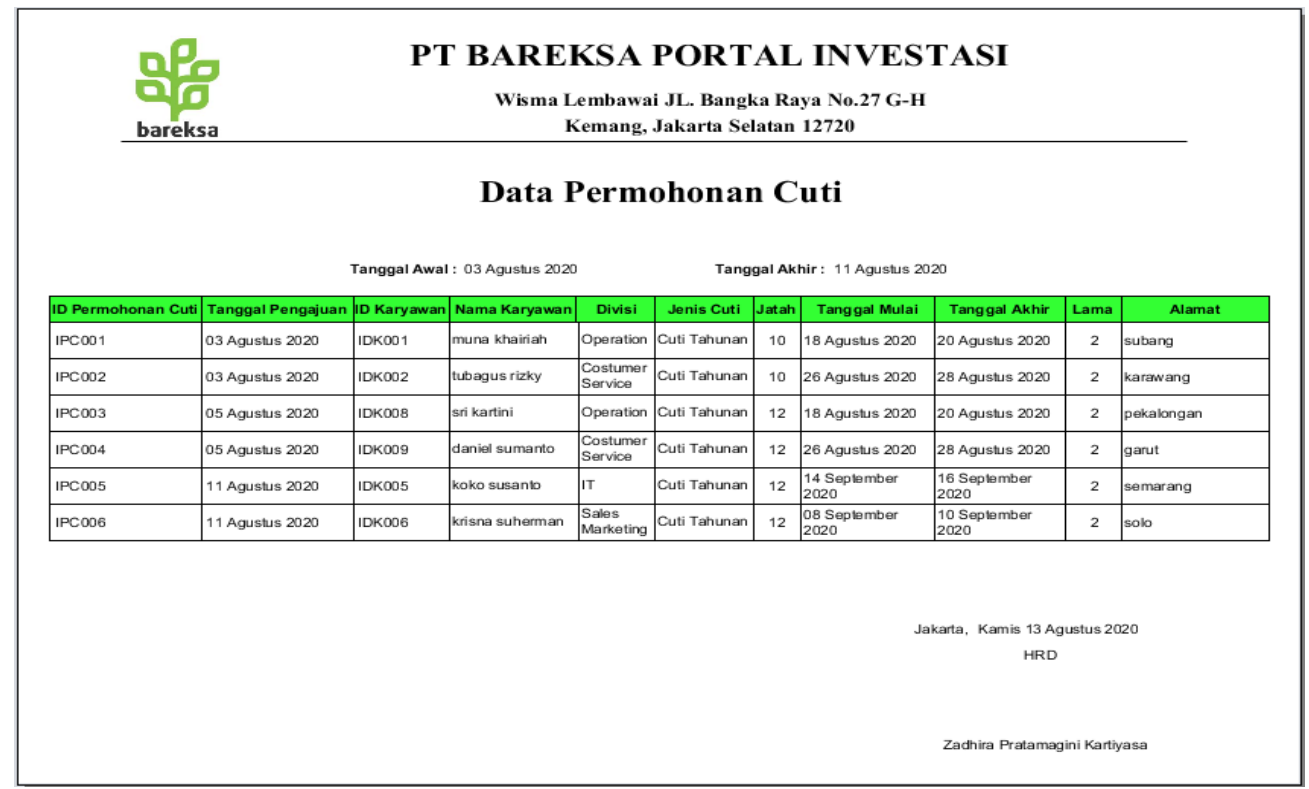

Gambar 9. Keluaran Permohonan Cuti

Keluaran Permohonan Cuti merupakan hasil dari cetak data penyewa pada form masukan data Permohonan Cuti yang berisikan data permohonan cuti yang akan melakukan pengajuan cuti. 


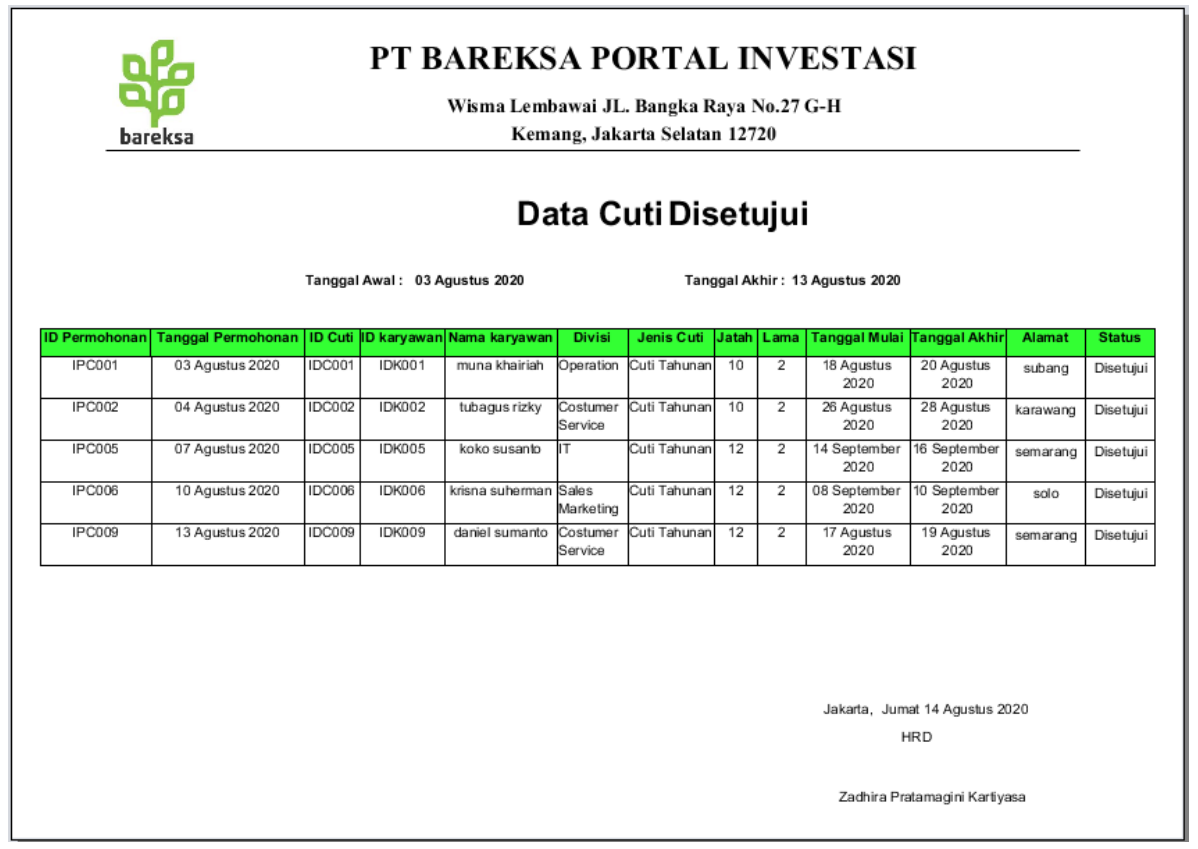

Gambar 10. Keluaran Data Cuti Disetujui

Keluaran Data Cuti Disetujui merupakan hasil dari cetak data Cuti disetujui pada form masukan data persetujuan yang berisikan data cuti disetujui

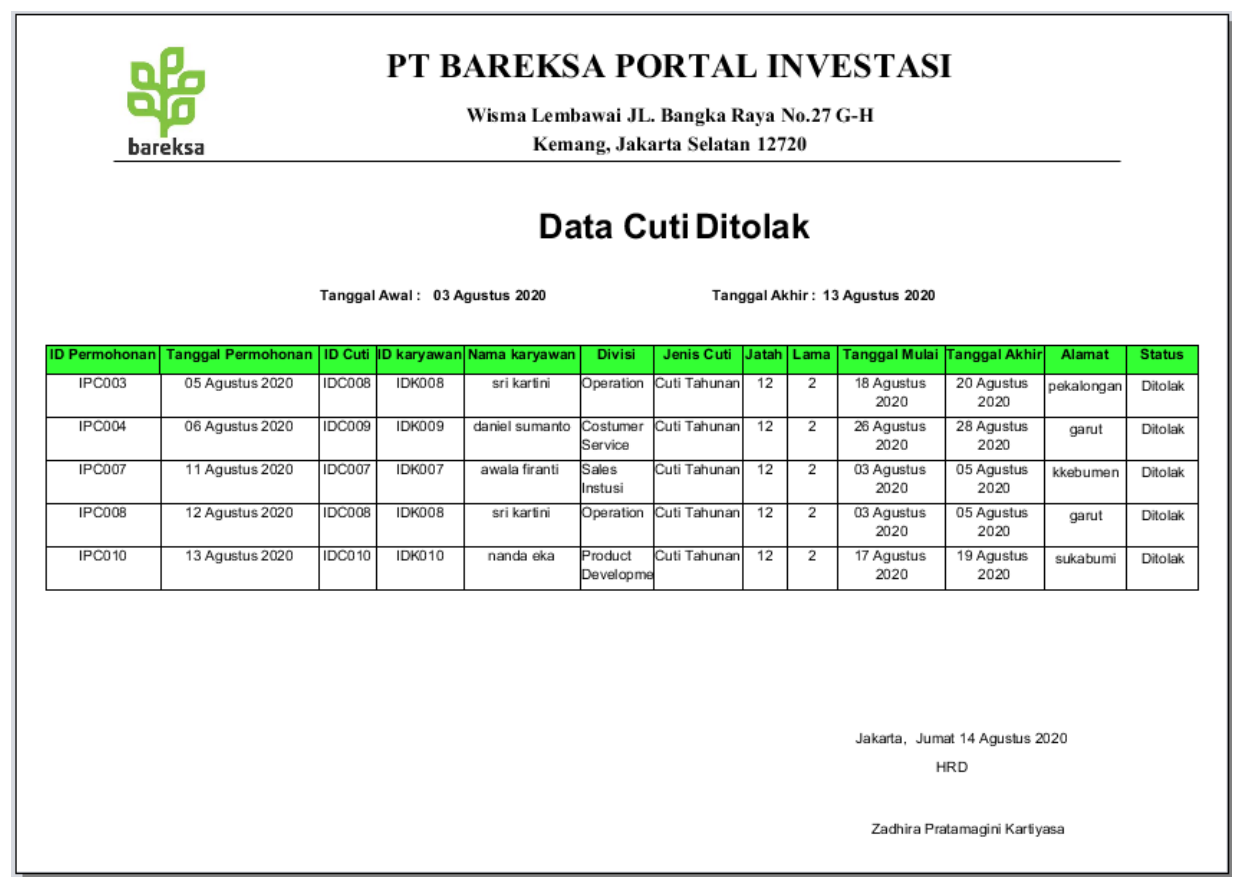

Gambar 11. Keluaran Data Cuti Disetujui

Keluaran Data Cuti Ditolak merupakan hasil dari cetak data Cuti ditolak pada form masukan data persetujuan yang berisikan data cuti ditolak 


\section{SIMPULAN}

Dengan dibuatnya perancangan sistem aplikasi permohonan cuti ini maka dapat disimpulkan sebagai berikut :

1. Sistem informasi PT Bareksa Portal Investasi telah terkomputerisasi dengan sistem aplikasi berbasis java

2. Karyawan lebih mudah mengetahui sisa cuti yang ia miliki

3. Waktu persetujuan yang diberikan kepala divisi menjadi lebih cepat

\section{DAFTAR PUSTAKA}

Basuki, A. T. (2011). Perancangan aplikasi sistem informasi cuti karyawan berbasis web pada PT Integrasi Tri Tama Cendekia (Skripsi). UIN Syarif Hidayatullah Jakarta: Fakultas Sains dan Teknologi.

Hakim, R. S. (2010). Buku Pintar Windows 7. Elex Media Komputindo. Jakarta.

Haryani, N. (2017). Sistem Informasi Pengambilan Cuti Pegawai Berbasis Desktop Pada PT Bs Logistics Batam (Skripsi). sekolah tinggi Manajamen informatika dan komputer GICI Batam.

Hermawan, I. (2019). Metodologi Penelitian Pendidikan (Kualitatif, Kuantitatif dan Mixed Method). Hidayatul Quran.

Hutahaean, J. (2015). Konsep sistem informasi. Deepublish.

Lubis, A. (2016). Basis Data Dasar. Deepublish.

Nazir, M. (2011). Metode Penelitian. Ghalia Indosesia.

Semiawan, P. D. C. R. (2010). Metode penelitian kualitatif. Grasindo.

Sukamto, \& Shalahuddin, M. (2015). Rekayasa Perangkat Lunak ( Terstruktur dan Berorientasi Objek) 2015. In Informatika Bandung.

Yakub. (2012). Pengantar Teknologi Informasi. Graha Ilmu. 